JMKSP (Jurnal Manajemen, Kepemimpinan, dan Supervisi Pendidikan)

Volume 7 Issue 1 (2022) Pages 82-97

ISSN 2614-8021 (Online) 2548-7094 (Print)

\title{
Personal Managerial Effectiveness: Future Vision, Current Reality and Identification of Gaps and Strengths
}

\author{
Slamet Wahyudi ${ }^{1}$ \\ ${ }^{1}$ Ubaya Polytechnic
}

Corresponding Author E-mail: slamet.wahyudi@ staff.ubaya.ac.id

Received 20 August 2021; Revised 23 December 2021; Accepted 6 January 2022

\begin{abstract}
This article focuses on the process on how an individual states future vision, current reality and finding the gaps between, in order to know his own strengths. Often we did not realize that our vision is too hard to achieve without considering the current reality. There are four tests I did to find out the gaps and strengths; these are including The McPhee Andrewartha, The Personality Test, The Big Five Test and Strength Finder. The result of the test shows some gaps and strengths for me to note. The four tests allow me to recognize some strength that I should work and improve. What is new here we focus only on the strengths we have, not the weaknesses. As pandemic is going on, effectiveness test could be a solution for us to perform better at the workplaces.
\end{abstract}

Keyword: Managerial Effectiveness, Future Vision, Current Reality

\section{Introduction}

This managerial effectiveness report consists of my future vision, current reality and an identification of gaps and strengths. Indeed, I also state my personal goals which cover both short and long term planning which include being happier, achieving life-career balance, and pursuing higher education. Accordingly I elaborate S.K.A.N (Skills, Knowledge, Attitudes and Networks) overview to analyze my future vision compared to my current action situation. In this report I include the results of my diagnostic tests from tools such as the McPhee Andrewartha Influence Dimension, Personality test, the Big Five Tests, and 
Morgan Gallup Strengths Finder. Before the conclusion, through this report, identification of gaps and strengths is presented followed by action plan as well.

In order to be an effective person, having objectives or future vision is absolutely crucial. According to Pickett (1998), one of the key factors which need to be considered to gain success and effectiveness is having clearly defined objectives. In addition, Tame (1993) confirms that a good vision will guide person or manager to have an effective life planning. Finding someone potential it is not simple task we need some strategy and tools to find out the best potential of one particular person or group of students (Aziz et. al, 2021)

Besides visions, there is another important interdependent factor needs to be hold in order to be effective, which is goals. Goals could be guidance, however not all of goals beneficial for future, therefore goals should be SMART means specific, measurable, achievable, realistic and timely specific (Updegraff, 2004). Goals, in other word, are missions, or specific things to achieve vision (Updegraff, 2004).

In the opinion of Mclean (1992) goals of each particular person are different, they can be grouped into personal and organisational goals. Personal goals contain happiness, success and financial security. Meanwhile, organisational goals include market growth, quality and share value (Mclean, 1992). Further in this report I will explore and analyse deeper to ensure that these actually can support me to achieve my future visions.

In this article, I incorporate three main future visions regarding life and career planning, in which I believe will be able to be achieved in the short and long term processes. My personal future visions are becoming happier and healthier person, balancing my family's business and my career, and having opportunity to study in higher educational level

I realise that happiness and health is a packet of effective person. I choose this as my future vision because this will impact on my daily performance. If I am happier I can have more networks and viewing life positively, next if I am healthy I will be able to perform and conduct my tasks in the best condition, such as reducing sick leave. Tal Ben Shahar (2007) claims that happiness is embedded in mind not in the ownership of good house, bank account and other material things. He emphasises that life is a learning journey; good achievement is encouraged but the process to achieve that is also crucial. On the one hand, maintaining good 
health will support us to be a happy person (Shahar, 2007). Moreover, Covey (1989) encourages us to accept happiness as a new pattern of habits. Hence, I believe by becoming happier and healthy person will give me a strong foundation and motivation in relation to achieve my second and third vision

Personally I feel that this vision is so ideal for me, due to the reason that I am the first son of my parents who should improve and expand my small family's own business to be stronger. On the other hand, I am also interested in gaining experience outside, for instance my first option is I want to work in educational sector as a lecturer, and then if I am qualified enough I want to work in a broadcasting company like TV or newsroom. Interestingly, from information I gather from colleagues who work as a lecturer, they said that lecturer has more flexible time compared to the other professions such as news presenter or reporters who should spend more time in the office and often work overnight.

I will accept the challenge to gain experience outside which is likely to be a lecturer but also give contribution to my family's business. In Drucker's (1999) point of view, managing ourselves is the clue to succeed, through understanding our strengths, values and how we best perform.

I find studying is able to support my knowledge thoroughly. Since I did my master degree in International Business which encourages student to do a lot of researches, I am motivated to do more and more research in the future. One way to do that is by continuing my study later. In this report I will give note that this is in line with my long term vision and if I work as a lecturer I believe higher education is compulsory. In addition, in the University I will learn more knowledge about how small medium enterprise like my family's business could survive in this globalization age.

It is obvious that by having this managerial effectiveness report I should explore and elaborate information regarding myself. Accordingly, I soon realize that it is essential to analyse my present facts and data in terms of skills, knowledge, appropriate attitudes and also my related networks in order to become an effective person as explained by Carlopio, Andrewartha and Amstrong (2005).

State of the art and novelty of this study is the fact that often we encourage students or others to learn something they not good enough in doing so, hence they hardly can succeed. I try to rotate this habit into encouraging other to improve what is good in one person, by focusing on the strength and the potential, 
I wish this way will gain success in the future. It is not good only for us as academician but also for parents out there. As Pandemic is going on, Academic Stress may happen to kids as student as well (Ahmad, 2021). It will help us to be less demanding to ourselves, others, kids and students on what they not good at doing so, accordingly it will help us to find out what is good on people and will work on that to gain the best result. We can start doing this from very early age, as (Rozalena and Kristiawan, 2017) stated that finding potential must be taken into action since earle childhood stage, hence parents and teachers may prepare better learning strategies.

\section{Methods \\ Diagnostic Tools}

In my opinion, it is essential to do some personal diagnostic test, so that I can use the tests result to analyse myself awareness, strengths and weakness. Further I will apply this result based on theories and practical evidence. According to Buckingham \& Clifton (2005), each personal is distinct to the others; therefore in order to be effective, analyzing natural talents and work on its strengths will transform someone to be an effective person. Moreover, Whetten \& Cameron (2007) argue that once someone realizes his self awareness, he will be able to have clear priorities, qualified time management and stress reduction skills. Below are four diagnostic tests review that I did before hand, after reviewing these tests result, I will identify the gaps between my current S.K.A.N and future visions, so that I can work on those gaps to reach my desired S.K.A.N.

\section{The McPhee Andrewartha}

This test was conducted through www.mcpheeandrewarta.com.au. In terms of my influence dimension (ID), there are six dimensions and one perceptual system followed by leadership/learning style which is derived from this diagnostic tool.

In general, I am happy with the test result, which shows that as an analyser I have met particular requirements such as having detail (+) focus, I am just wondering if this would lead me to be a perfectionist person. Beside that I have linear/lateral way of thinking, this is what I want to build in the future so not merely do jobs orderly but can be randomly depending on the situation. However, from this ID test result, I notice several things which are inconsistent with my 
current reality S.K.A.N, for instance, under emphasis dimension, it claims that I can work calmly under pressure, I tend to avoid working under pressure, I would prove this notification in the future though. I am also often taking more works rather than less work, these matches with my self evaluation, I want to simplify my life.

In term of timing and relationship, I accept that I often miss opportunities since I consider things too thoroughly, therefore I may not finish things completely, yet like to lead the way relationship goes. Recently, as student and part-time worker I will use my analysis/learning skills and emphasis to be able work effectively in doing University assignments and workplace duties. Regarding my future vision, especially how to balance my family's business and personal career outside, I think I will use these skills as my strengths to achieve that. Hawkins (1994) mentions that it is not about us as human being learn in different way, instead our understanding on how we learn. Analyser has strength in pure learning situation that requires researches, organised and methodological system (Carlopio et el, 2007). However Carlopio et al, (2007) mentions that analyser cannot do thing without understanding reason and context.

\section{The Personality Test}

My second diagnostic tests tool choice is the personality tests from www.personalitytest.net, by which I find my self belongs to ENFJ personality group. These stand for Extraverted (E), Intuitive (N), Feeling (F) and Judging (J) (personality test centre, 2007). Based on this, I will briefly explore the description of my personality types.

E means Extraverted, according to personality test centre (2007), I am energise, talkactive, always taking part on a conversation and seminars, more over tending to ask other people's opinions in the workplaces or classes. However, I am claimed not to listen carefully to others. Unfortunately, I cannot spend too much time alone, since I need others to talk to and socialize.

$\mathbf{N}$ means Intuitive, intuition is the opposite of sensor, therefore I try to get information from understanding meanings, relationship and possibilities, and I see more general thing rather than details and specifics (personality test centre, 2007).

F means Feeling, here I will avoid conflict and agree to make harmony, and usually I will accommodate people's need then mine, yet care about most of 
decisions' impact on others. Since there is neither 100 percent feeler nor 100 percent thinker (personality tests centre, 2007). I therefore might use logic whenever it is necessary.

J means Judging, based on personality test centre (2007); I am a judger who is very well scheduled, structured, scheduled, on time and ordered. Then I am a morning person, who always willing to wake up early morning, and unhappy if can not meet the plans (Hogan \& Champagne, 2002).

This second test, I find contradictive to the influence dimension test (ID) before, especially when it mentions about intuition. In the ID test I have detail (+) focus which focuses much on things very thoroughly. However, this personality test claims me having a strong intuition and see things unspecific. Hogan \& Champagne (2002) state that no person foot shape is true or false as there is neither person personality is right or wrong.

\section{The Big Five Test}

The third test I have taken is the big five test from www.SimilarMinds.com. This test results in some identification of myself in terms of five factors, including extroversion, orderliness, emotional stability, accommodation and inquisitiveness as shown in Table 1.

\section{Table 1 Result of Big Five Test}

\begin{tabular}{|c|c|c|}
\hline Extroversion & |||||||||||||||| & $64 \%$ \\
\hline Orderliness & |||||| $\mid$ & $78 \%$ \\
\hline Emotional Stabilit & ${ }_{\nu}|\|||||||||||| \mid$ & $64 \%$ \\
\hline Accommodation & $|\||||||||||||||$ & $64 \%$ \\
\hline Inquisitiveness & \|\|\|\||| & $66 \%$ \\
\hline
\end{tabular}

Source: $\underline{w w w . S i m i l a r M i n d s . c o m}$ 
Furthermore, I will review the result of this test briefly.

Extroversion, my score is 64 percent which is moderately high, further this categorisation supports me to be talkative, interested in social activities, and build relationship to gain personal interests.

Orderliness, 78 percent is high according to SimilarMinds (2007), it suggests that I am overly organized, neat; task oriented and seems to ignore too much flexibility, variety, fun and spontaneity.

Emotional Stability, again 64 percent is moderately high so it shows that I am optimistic, secure and calm, yet relaxed at the same time.

Accommodation, the result is 64 percent which is moderately high, it reviews me having kind personality that naturally build on me. Trust is a big issue for me, however I prefer people who is eager to help each other.

Inquisitiveness, 66 percent is quite high means that I am often curious about something new, has good imagination and intellectual, however I am probably reluctant to apply these into practical life.

\section{Strength Finder}

The last test is from www.strengthsfinder.com. As far as I concern, the purpose of this diagnostic tool is to find out the strengths and other potentials talent people own inside (Buckingham \& Clifton, 2005). These two scholars, Buckingham \& Clifton (2005), believe that most organisation consider more on people weakness that lead to flaw assumption on employees. Later, I will integrate my top five positive talents as the result of this test.

Strategic, this refers to my ability to see the patterns of sophisticated issues; furthermore I can work in one matter with several possibilities of solution.

Relator, it means that I enjoy work with people, as I like to make long term relationship. I admit the risk of the relationship since I believe to be able to tackle it.

Includer, this suggests that I am willing to encourage others to be a part of the group where I belong, I am reluctant to do judgment on particular person in public, because I think it is unnecessary. 
Learner, which describes me having good motivation to learn continuously, although I tend to value the process rather than the final results.

Self-Assurance, which encompasses me, is a confident person in terms own life management, means faith is my strength, I could be quite or loud person depending on the situation.

Generally, what this test result encourages me to realise what strengths I own since I often ignored it and merely focus on my weaknesses. For instance I see there is a lack of confident I feel at the moment, but from this test, I believe I will improve my strength in term of self-assurance so that I can have better self confident, but of course not overly confident. Secondly, I also find Gaps in my current S.K.A.N to my future vision in terms of strategy, since at the moment I just focus on type of jobs which have been set up for me, I, more or less, have the potential to find more alternative solutions for my family's business matters in the future.

\section{Identifying Gaps and Strengths}

Before organizing action plans, I will compare my current reality S.K.A.N to the future S.K.A.N of mine to effectively achieve my visions. From this comparison then I could analyse the Gaps which guide me to work on that. Another crucial thing in which I will address here is my core strengths.

In order to accommodate myself in a situation which allows improvement, I recognize that there is one gap that I will develop which is the gap between my feeling \& thinking. In addition, I will develop my main strengths in terms of strategy and learning. In the opinion of Seagal \& Horne (1997), attitude toward balancing logic and feeling will guide societies to live harmoniously. Therefore, I decide to develop this gap, from the personality test I am belonging to feeler, I want to be able to bridge myself from feeler but also have a good thinking as well. In order to live harmoniously I think I need to know when I have to involve my feeling and when logic is appropriate. I am delighted with my abilities to be able to structure strategies and my eagerness to learn; hence I think these are my main strengths to be developed in the upcoming future.

\section{Feeling (Emotion) and Thinking (Rational)}

Hogan \& Champagne (2002) explains that there are four types of typology dimensions pair, which are introversion-extraversion, intuition-sensing, feeling- 
thinking and perceiving-judging. Accordingly, I will focus on my feeling and thinking.

The feeler makes judgment based on personal value, empathy and warmth (Hogan \& Champagne, 2002). On the other hand, thinker makes judgment based on analysis, data and evident (Hogan \& Champagne, 2002). The obvious Gaps that I notice here that, I tend to use my feeling, especially when the decision that I develop is related to many people, although I have prepared many data and evidence still I consider my feeling. This situation often wastes my research time and often I take wrong decision.

On the one hand, Ellis (1973) cited in Pfeiffer (1991) who develop theories on RET or rational emotive therapy, claims that rational or thinking and empathy or feeling are pretty much influenced by the prone of people to their self-talk and self-doubt. Further Ellis (1973) cited in Pfeiffer (1991) suggest people to be assertive but also supportive to do the therapy. This RET creates ABC theory that agrees with the role of emotions and behaviours; however encourages more thinking in solving problems (Bernard, 1986). Bernard (1986) states that every time we make irrational decision, we should remind ourselves to be objectives. What makes irrational decision is feeling, particularly our behaviour as well, further by changing habits into more rational thinking, we will have different view of life, world and our self (Bernard, 1986). Goleman (1998) argue that IQ as an intellectual skills are important, yet it is even better to have emotional intelligence as well.

\section{Strategic}

Buckingham \& Clifton (2005) integrate that strategic people are able to find out the best possible solutions from a very sophisticated problem. I found myself always willing to ask about the agenda behind events. This goes side by side with the opinion of Buckingham \& Clifton (2005) who state that people with strategic type always keep thinking of patterns, they often ask about what if this process actually used the other systems or ingredient, then what is going to happen. In doing so, understanding what strategy to use is not appropriate yet (Pleffer \& Sutton, 1999). Hence to enhance that we have to transform out knowledge and strategies into practice, next understanding the cause of events and problems is beneficial to make a good and sound strategy (Pleffer \& Sutton, 1999). 


\section{Learning}

During my study process in the schools and universities that I went to, I am very motivated to study and learn knowledge. I do realise that having good marks for my final exams and assignment are essential, yet I find myself satisfied with the way I learn. Kolb, Rubin \& Osland (1991) explain that most of the people associate learning process with formal educational system, but actually learning could be trough informal institution; moreover the fast changing world requires the ability to learn as the most important skill. Since everybody is unique, therefore they are also having different way of learning. There are four models in learning process which are concrete experiences, testing implications of concepts in new situations, formation of abstract concepts and generalization, and observation and reflections (Kolb et al, 1991).

From the mcpheeandrewarta test, my learning style is analyser. Kolb et al, (1991) argues that no model is best, yet to help improve individual and organisational learning, there are two important notes to be considered, firstly learning should have clear purposes, and then learning also needs to balance action and reflection, analytical and generalisation. Smith (1992) says that effective manager should have a daily learning diary, so he can learn from his experience. I start to develop a habit to write a diary which contain my personal learning diary in weekly basic, hopefully I will be able to benefit from this, for instance if I happen to take wrong decision, then in the future I will try my best to avoid the same action.

\section{Results and Discussion}

\section{Action Plans}

In the statement of Fagioli, Hommel \& Schubotz (2007), to achieve better performance we need to have tasks stimulus dimensions to be implemented in the manual plans. Moreover, Combs, Nadkarni \& Combs (2005) suggest that a good achievement always starts with a well defined plans, since it has positive impacts on the process. In addition, through actions plan we can set our goals attainment and some alternative strategies (Brodscholl, Kober \& Higgins, 2005). In this next part I will state my actions plans, including the goals, method and resources. 


\section{Gaps on Action Plan}

\section{Table 2: Gaps Action Plan}

\begin{tabular}{|c|c|}
\hline Gaps & Emotional and Rational \\
\hline Goals & Understanding the appropriate usage of emotion (feeling) and rational (thinking) \\
\hline Standard & $\begin{array}{l}\text { Becoming more objective toward problems } \\
\text { Able to harmonise relationship with others } \\
\text { Also have the ability to be logical and assertive in decision making process } \\
\text { Increase awareness of EQ and also maintain IQ }\end{array}$ \\
\hline Short term & Immediately \\
\hline Long term & $\begin{array}{l}\text { Within five to ten years } \\
\text { life long }\end{array}$ \\
\hline Actions & $\begin{array}{l}\text { Apply RET (Bernard, 1986) } \\
\text { Think logically, and analyse even with rational (Pfeiffer, 1991) } \\
\text { Distinguish the appropriate function of feeling and thinking (Bernard, 1986) } \\
\text { Use feeling to develop long term relationship, use thinking to make decision (de } \\
\text { Bono, 1992) }\end{array}$ \\
\hline Assessment & $\begin{array}{l}\text { Ask friends and colleagues or co-workers to give comments and feedbacks } \\
\text { Self reflection trough learning journal } \\
\text { Monitoring the decision making process that I have done }\end{array}$ \\
\hline Resources & $\begin{array}{l}\text { Learn emotive and rational decision making process from personal and } \\
\text { organisational behaviour books } \\
\text { Read EQ and IQ development books and journals } \\
\text { Do consultations with people who expert on this issue }\end{array}$ \\
\hline
\end{tabular}




\section{Strength on "Strategic" Action Plan}

\section{Table 3: Strategic Action Plans}

\begin{tabular}{|c|c|}
\hline Strength & Strategic \\
\hline Goals & $\begin{array}{l}\text { To be more competent to make business strategic planning } \\
\text { Ability to build a sound and precise strategies }\end{array}$ \\
\hline Standard & $\begin{array}{l}\text { To give more alternative strategies for one particular matter } \\
\text { Ability to see the pattern of issues }\end{array}$ \\
\hline Short term & $\begin{array}{l}\text { Within the next } 6 \text { weeks } \\
\text { Immediate }\end{array}$ \\
\hline Long term & $\begin{array}{l}\text { 5-10ears } \\
\text { the rest of my career and life }\end{array}$ \\
\hline Actions & $\begin{array}{l}\text { Always asking for alternatives (Buckingham \& Clifton, 2005) } \\
\text { Try to notice the consequences before the other people does (Buckingham \& Clifton, } \\
\text { 2005) } \\
\text { Planning and reaction (Buckingham \& Clifton, 2005) }\end{array}$ \\
\hline Assessment & $\begin{array}{l}\text { Monitoring the development of strategies } \\
\text { Feedback from friends, families and co-workers or employees }\end{array}$ \\
\hline Resources & $\begin{array}{l}\text { Learn from strategic management books } \\
\text { Actively join a discussion group on strategic management topics }\end{array}$ \\
\hline
\end{tabular}




\section{Strength on "Learning" Action Plan}

Table 4: Learning Action Plans

\begin{tabular}{|c|c|}
\hline Strength & Learning \\
\hline Goals & $\begin{array}{l}\text { Ability to graduate on time } \\
\text { Ability to absorb knowledge better } \\
\text { Ability to learn formally and informally }\end{array}$ \\
\hline Standard & $\begin{array}{l}\text { How to be innovative and creative } \\
\text { Increasing performance }\end{array}$ \\
\hline Short term & Immediately \\
\hline Long term & The rest of my life \\
\hline Actions & $\begin{array}{l}\text { Reduce idle time } \\
\text { Do challenging tasks (Carlopio, et al, } 2005 \\
\text { Give praise to myself after finishing learning something (Carlopio,et al, 2005) }\end{array}$ \\
\hline Assessment & $\begin{array}{l}\text { Ask feedback from tutors and teachers } \\
\text { Monitor learning progress trough learning diaries }\end{array}$ \\
\hline Resources & $\begin{array}{l}\text { Library } \\
\text { University and schools } \\
\text { Courses } \\
\text { Internet and discussion clubs }\end{array}$ \\
\hline
\end{tabular}

\section{Conclusion}

Through this effectiveness report, I have the opportunity to explore my personality. Moreover the results of the diagnostic test tools above allow me to consider my current and future S.K.A.N. Hence I can work on the gaps and improve my strengths. I believe that the theories from many scholars who are experts in psychology and self help actually give me pathway to my real practical life. 
In the final analysis, I will focus more on my ability to balance feeling and thinking since I find gaps between these two. Personally this report will be my guidance to be more effective person in the future. Furthermore, from the diagnostic test I did before I realize that actually I need to focus more on my selected top strengths which are strategic and learning, these two obviously will complement to each other regarding my journey process as an ordinary person.

\section{Acknowledgement}

Here I would like to thanks all of Ubaya Polytechnic Staffs and Lectures who always support me in preparing this paper, especially my colleague in Secretary and marketing management study program. Furthermore, thanks a lot to the team of JMKSP that gave several valuable suggestions in the process of peer review.

\section{References}

Ahmad, M. (2021), "Academic Stress: how extrinsic motivation and self-efficacy affect", (JMKSP) Jurnal Manajemen, Kepemimpinan, dan Supervisi Pendidikan, Vol 6 Issue 2 (2021), pp. 164-180.

Aziz, A.A., Budiyanti, N., Ahmad, N., \& Suhartini, A. (2021), "The potential of Islamic boarding school and their effort of development and fostering at pesantren persatuan Islam 1-2 Bandung”, (JMKSP) Jurnal Manajemen, Kepemimpinan, dan Supervisi Pendidikan, Vol 6 Issue 2 (2021), pp. 352-371.

Buckingham, M. \& Clifton, O. D. (2005), Now discover your strengths: How to develop your talents and those of the people you manage, $2^{\text {nd }}$ edn, Pocket Book, London.

Bernard, M. E. (1986), Staying rational in an irrational world, McCulloch Publishing, Cariton.

Brodscholl, C. F., Kober, H. \& Higgins, T. E. (2007), "Strategies of selfregulation in goal attainment versus goal maintenance", European Journal of Social Psychology, Vol. 37, pp. 628-648.

Carlopio, J., Andrewartha, G. \& Armstrong, H. (2005), Developing management skills: A comprehensive guide for leaders, $3^{\text {rd }}$ edn, Pearson Education, NSW.

Covey, S. R. (1989), The seven habits of highly effective people, Simon \& Scuster, New York. 
Combs, M. G., Nadkarni, S \& Combs, W.M. (2005), "Implementing affirmative action plans in multinational corporations", Oranizational Dynamics, Vol. 34, No. 4, pp. 346-360.

Drucker, P. F. (1999), “Managing oneself”, Harvard Business Review, Vol. 77, No. 2, pp. 65-74.

De Bono, E. (1992), "The six thinking hats" in Serious Creativity, Harper Collins, London.

Fagioli, S., Hommel, B. \& Schubotz, I. R. (2007), "International control of attention: action planning primes action related stimulus dimensions", Psychological Research, Vol. 72, pp. 22-29.

Goleman, D. (1998), “What makes a leader?", Harvard Business Review, Vol. 11/12, No. 1, pp. 93-102.

Hogan, R. C. \& Champagne, D. (2002), Personal style inventory in "Project Management Book 2", CeLTS, Monash University, pp. 46-57.

Kolb, D. A., Rubin, M. \& Osland, J. (1991), The learning style inventory, Vol 5, Prentice-Hall, New Jersey.

Mclean, J. J. (1992), Enlightened self-interest, win-win thinking and relationships, personal and organisational effectiveness and word peace: Nothing new but a paradigm shift for many!, Paper presented at the fifth International Conference on Thinking, Townsville.

McPhee Andrewartha revised 2007, viewed 12 August 2007, www.mcpheeandrewartha.com

Pickett, L. (1998), "Competencies and managerial effectiveness: Putting competencies to work", Public Personnel Management, Vol. 27, No. 1, pp. 103-115.

Pfeffer, J. \& Sutton, R. (1999), "Knowing what to do is not enough: Turing knowledge into action, California Management Review, Vol. 42, No. 1, pp. 83-108.

Pleiffer, J. W. (1991), "Rational-emotive therapy", Theories and Models in Applied Behavioural Science, Vol, 1, pp. 47-52.

Rozalena \& Kristiawan, M. (2017), "Pengelolaan pembelajaran PAUD dalam mengembangkan potensi anak usia dini" (JMKSP) Jurnal Manajemen, Kepemimpinan, dan Supervisi Pendidikan, Vol 2 Issue 1 (2017), pp. 76-86.

Smith, B. (1992), Learning diaries, Harcourt Brace Jovanovich, NSW.

SimilarMinds revised 2007, viewed 12 August 2007, www.SimilarMinds.com.

Strengthfinder revised 2007, viewed 1 September 2007, www.strengthsfinder.com 
Personality Test Centre revised 2007, viewed 31 August 2007, www.personalitytest.net

Seagal, D. \& Horne, D. (1997), Human dnamics: A new framework for understanding people and realizing the potential in our organizations, Pegasus Communications, Cambridge.

Tame. J. (1993), "Life planning for executives", Long Range Planning, Vol. 26, No. 5, pp. 93-102.

Tal Ben Shahar revised 2007, viewed 30 August 2007, www.talbenshahar.com

Updegraff, S. (2004),"Maximising human potential: Tips to foster personal effectiveness", Employment Relations Today, Vol. 31, No. 1, pp. 43-50.

Whetten, A. \& Cameron, S. K. (2007), Developing management skills, $7^{\text {th }}$ edn, Prentice Hall, New Jersey. 